ISSN 1392-3196 / e-ISSN 2335-8947

Zemdirbyste-Agriculture, vol. 100, No. 2 (2013), p. 175-178

DOI $10.13080 /$ z-a.2013.100.022

\title{
Frost resistance is associated with development of sour cherry (Prunus cerasus L.) generative buds
}

\author{
Inga STEPULAITIENE $\dot{1}^{1}$, Audrone ŽEBRAUSKIENE ${ }^{2}$, Vidmantas STANYS ${ }^{1,2}$ \\ ${ }^{1}$ Institute of Horticulture, Lithuanian Research Centre for Agriculture and Forestry \\ Kauno 30, Babtai, Kaunas distr., Lithuania \\ E-mail: i.stepulaitiene@lsdi.lt \\ ${ }^{2}$ Aleksandras Stulginskis University \\ Studentų 11, Akademija, Kaunas distr., Lithuania
}

\begin{abstract}
Spring frost is a limiting factor for yield and its stability in sour cherry. Shoots of sour cherry (Prunus cerasus L.) 7 cultivars were artificially frozen at $-4^{\circ} \mathrm{C}$ for 30 min at the Department of Orchard Plant Genetics and Biotechnology of Institute of Horticulture, Lithuanian Research Centre for Agriculture and Forestry. Dynamics of phenological phases was observed and probability of spring frost was evaluated. Cultivars were divided into two groups according to resistance to spring frost at different phenological phases. The first group consisted of plants that were most sensitive to frost in the fruit germ phonological phase. The second group consisted of the cultivars which were mostly sensitive in full bloom phase. It was established that resistance of sour cherry cultivars to spring frost is a combination of several biological components. Sour cherry resistance to spring frost depends on the level of development of generative buds during spring frost; stability of bearing depends also on the duration of most susceptible phenological phases and spring frost probability during these phases. Plants of 'Orkolija' cultivar were the most injured at $-4^{\circ} \mathrm{C}$ in full bloom phase as compared to other phonological phases and differed significantly compared to other cultivars studied. Stable bearing occurs in the sour cherry cultivars with short phenophases in which generative organs are most vulnerable to frost, and these phases occur when the probability of spring frost is low.
\end{abstract}

Key words: phenological phase, Prunus cerasus, spring frost.

\section{Introduction}

Approximately 150 species are found in Prunus subgenus Cerasus and a couple of them are commercially important (Ansari, Davarynejad, 2008). Sour cherry (Prunus cerasus L.) due its nutritional value is the most widespread stone fruit species in Lithuania. Sour cherries are frequently damaged by spring frost, which damages pistils and ovaries. As a result, the amount of marketable production dramatically decreases (Rodrigo, 2000).

Floral buds of fruit trees are resistant to low temperature impact while in dormancy, but later in spring, the period of dormancy ends, plant begins to grow and resistance to cold gradually decreases (Iezzoni, 1985). It was shown that sour cherry is the most susceptible to spring frosts in first white, full bloom and ovaries developing after flowering (fruit ovaries) phases (Iezzoni, 1985; Szabo et al., 1996; Stepulaitienè, Stanys, 2009). In this phase the spring frost can occur unexpectedly and the opportunity to cold harden is not present (Rugienius, Stanys, 2001). Damage of open generative buds, flowers and fruit ovaries depends not only on temperature (frost intensity), but also on frost duration.

Damage by spring frost may be reduced using agronomic practices though more effective technique is growing frost-resistant cultivars. It was established that the duration of V-VIII organogenesis stages (Куперман и др., 1982) in blackcurrant depends on genotype (Duchovskis et al., 2000); spring frost mostly damages generative organs of plums in VIII and IX organogenesis stages, before and during flowering (Duchovskis et al., 2007), consequently breeding should be aimed at selecting plants with long organogenesis stages in which generative organs are resistant, and with short stages in which generative organs of plants are susceptible to spring frost. Miranda and co-authors established that slowly developing buds are more resistant to cold than faster developing buds (Miranda et al., 2005).

Floral bud development is determined by plant genotype, but environmental conditions may trigger significant fluctuations of trait expression in cultivars. Bud development is influenced by plant age and healthiness, bud positioning and density in the shoot, climatic conditions, geographical area, agrotechnical methods, usage of pesticides (Szalay, 2006). Higher temperature in late winter and early spring fasten plant butonisation and flowering (Walther, 2003). It was shown, that microsporogenesis process differs not only depending on genotype but also varies in different shoots from the same plant. Microsporogenesis first starts in floral buds in clustering flowering heads (Szalay, 2006).

When breeding cold resistant sour cherry cultivars, it is important to select genotypes with very short phenological phases when buds, flowers and fruit ovaries are most susceptible to frost.

The data on resistance of sour cherry generative organs to spring frost and factors influencing the resistance is lacking. Resistance of other stone fruit plants - peach and apricot is studied more comprehensively.

The aim of this work is to study development of sour cherry generative organs and their resistance to spring frost. 


\section{Materials and methods}

The study was conducted at the Department of Orchard Plant Genetics and Biotechnology of Institute of Horticulture, Lithuanian Research Centre for Agriculture and Forestry and at stone fruit orchard, established in 2002. A total of seven sour cherry accessions including two cultivars developed in Lithuania ('Notè' and 'Vytèny žvaigždè'), two cultivars from Russia ('Orkolija' and 'Rovesnica'), one cultivar from Poland ('Lucyna'), one cultivar and a hybrid from Hungary ('Pandy 301' and M 323, respectively) were used in this study.
Dynamics of phenological phases of sour cherry fruiting shoot flowering buds was observed from the $15^{\text {th }}$ of March to pollen formation in 2010-2012. Generative development of a flower was established using Nikon eclipse 80i microscope (ocular 20 ${ }^{\mathrm{x}}$, objective-lens $40^{\mathrm{x}}$ ), anthers dyed with acetocarmine were studied. Buds of 3 clustering flowering heads (9-15 buds) were microscoped daily. The developmental stage was fixed when more than half of buds reached the phase. The following phases were established: mother cells, tetrads, pollen (Fig. 1).
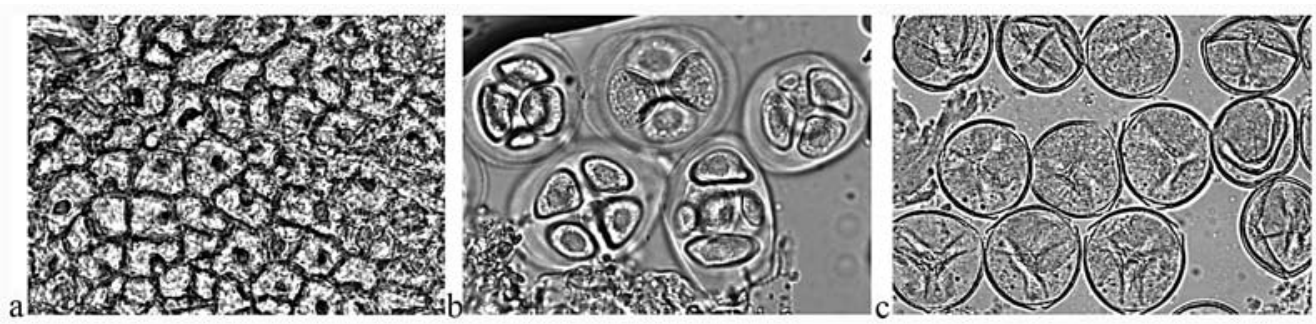

Figure 1. Sour cherry generative development phases: a) mother cells, b) tetrads, c) pollen

Phenologicalobservations of sourcherrycultivars were performed daily. The following phenological phases of developing generative bud were fixed: swollen bud, side green, green tip, tight cluster, open cluster, first white, full bloom, fruit ovaries (Stepulaitienè, Stanys, 2009). The beginning of phenophase was fixed when $10 \%$ of generative buds on clustering flowering heads reached the described phase. Resistance of sour cherry to spring frost was established in a controlled laboratory environment. Unhardened shoots were frozen at swollen bud, side green, green tip, tight cluster, open cluster, first white, full bloom, fruit ovary phenological phases. Shoots from all studied cultivars were placed into polyethylene bags and were transferred into the climatic chamber "Sanyo MIR-253" (Japan) at $0^{\circ} \mathrm{C}$. The temperature was gradually decreased to $-4^{\circ} \mathrm{C}$ at $1^{\circ} \mathrm{C}$ per $30 \mathrm{~min}$ step (Guerriero et al., 2006). The shoots were held at $-4^{\circ} \mathrm{C}$ for $30 \mathrm{~min}$. Later shoots were put into the pots with water, transferred

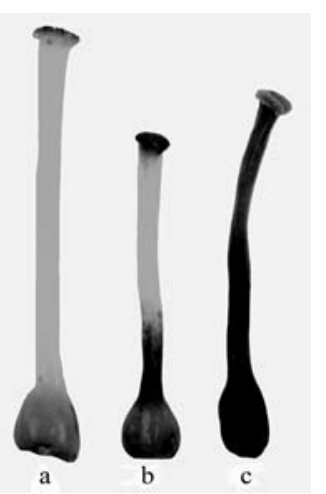
to a climatic chamber and held at $+4^{\circ} \mathrm{C}$. Frost-damaged flowering buds were evaluated visually three days later. Flowers with brown or black carpel (ovaries and styles) (Fig. 2) and fruit ovary (Fig. 3) were considered damaged. Control shoots were held at $+4^{\circ} \mathrm{C}$. Sum of active temperatures for a certain period was calculated adding average daily temperature $\geq+3^{\circ} \mathrm{C}$ starting on the $1^{\text {st }}$ of February.

Figure 2. Flowers with: a - undamaged carpel, b and ccarpel damaged by frost
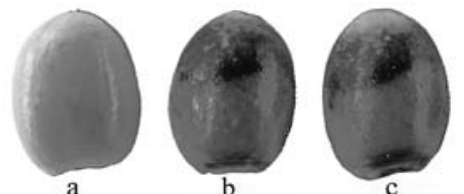

Figure 3. Ovaries developing after flowering: a undamaged, $\mathrm{b}$ and $\mathrm{c}$ - damaged by frost

The probability of spring frost was calculated using the 23-year data on minimal daily temperature $\left(\leq+5^{\circ} \mathrm{C}\right)$ obtained from Kaunas Meteorology Station (1990-2012). The temperature was measured at $1.5 \mathrm{~m}$ height. Leinonen and Hänninen (2002) suggest that the probability (p) of spring frost for a day (i) is a ratio between year number $(\mathrm{m})$ when minimal temperature $\left(\mathrm{t}_{\min }\right)$ was lower than threshold and total number of observation years $(\mathrm{n})$ :

$$
p_{i}=\frac{\sum_{i=1}^{m} t_{\min }}{n} \text {, where } \mathrm{p}_{\mathrm{i}}-\text { probability of spring }
$$

frost for a day, $\mathrm{t}_{\min }^{n}-$ minimal day temperature.

Excel package.

Data was processed using Microsoft Office

\section{Results and discussion}

It was shown that generative organs of cold treated sour cherry floral buds were undamaged in phases before and during meiosis-swollen bud, side green, green tip and tight cluster (Stepulaitiene, Stanys, 2009). Therefore negative temperature up to $-8^{\circ} \mathrm{C}$ is not harmful to generative sour cherry organs while in these phases. Floral buds in later phenological phases were cold treated at $-4^{\circ} \mathrm{C}$ (Fig. 4). Injury symptoms, brown or black ovaries and styles on generative organs emerged in first white, full bloom, fruit germ phenological phases. It was established that different cultivars were unequally injured in first white, full bloom and fruit germ phenological phases. Cultivars were divided into two groups according to resistance to spring frost in different phenological phases. Plants from the first group were injured in fruit germ phenological phase. This group included cultivars 'Notè', 'Pandy 301', 'Lucyna', 'Vytènų žvaigždè', 'Rovesnica' and hybrid M 323. The second group included cultivar 'Orkolija'; its flowers were the most susceptible to cold. Injury of generative organs of this cultivar was the highest and significantly different from other cultivars at $-4^{\circ} \mathrm{C}$.

The data obtained after cold treatment of sour cherry is consistent with field observations from different places. Szabo et al. (1996) established that when generative organs are in first white phenological phase and temperature dropped to $-2^{\circ} \mathrm{C}$, some flowers of 'Érdi bőtermő', 'Érdi nagygyümölcsü', 'Meteor corai' cultivars were injured. Almost $100 \%$ of flowers were damaged when temperature dropped to $-2.5^{\circ} \mathrm{C}$. Iezzoni (1985) stated that $10 \%$ of generative buds of 'Montmorency' cultivar were injured in first white phase at a temperature of $-2.8^{\circ} \mathrm{C}$, while $90 \%$ at a temperature of $-4.5^{\circ} \mathrm{C}$. In full bloom phase, $10 \%$ of generative buds 


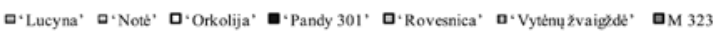

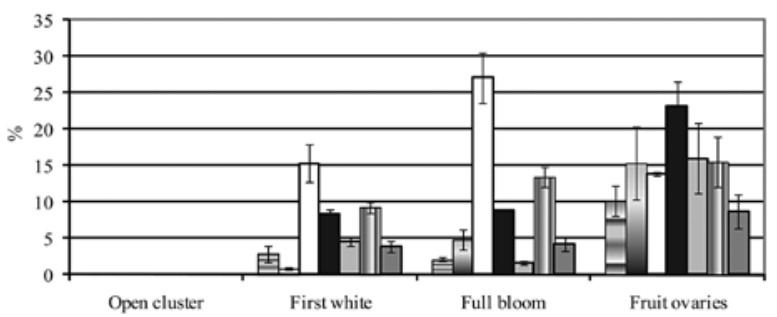

Figure 4. Injury of sour cherry generative buds in different phenological phases at a temperature of $-4^{\circ} \mathrm{C}$ (mean and standard deviation are shown)

were damaged at $-2.2{ }^{\circ} \mathrm{C}$, and $90 \%-$ at $-3.9^{\circ} \mathrm{C}$. Polish scientists established that spring frost up to $-4^{\circ} \mathrm{C}$ during flowering did not reduce yield considerably (Szpadzik et al., 2009). After the evaluation of spring frost damage to sour cherry cultivars we may state that resistance to spring frost is mostly determined by genetic components and by development phases, related to physiological state of the plant. Many scientists predict that plant vegetation in Northern latitude starts earlier due to climate change (Linkosalo et al., 2000; Anisimov et al., 2003; Romanovskaja, Bakšienè, 2011). It was established that the sum of active temperatures (SAT) for beginning of certain phenological phase in sour cherry varied depending on the cultivar (Fig. 5). Average SAT $\left(\geq 3^{\circ} \mathrm{C}\right)$ for mother cell phase in all studied sour cherry cultivars was $123^{\circ} \mathrm{C}$. SAT value required for the beginning of meiosis was lower than average for cultivars 'Orkolija', 'Pandy 301', 'Vytènu žvaigžde'' and hybrid M 323. Meiosis in 'Lucyna' cultivar started later than in other cultivars, because its SAT for beginning of meiosis was $25^{\circ} \mathrm{C}$ higher than average SAT in other studied cultivars.

Average SAT $\left(\geq 3^{\circ} \mathrm{C}\right)$ for first white phase was $416^{\circ} \mathrm{C}$. Hybrid M 323 had the lowest SAT value $\left(387^{\circ} \mathrm{C}\right)$ for this phase. Thus first white phase in this hybrid started earlier than in other cultivars at the time of increased probability of spring frost. Significantly higher than average SAT $\left(433^{\circ} \mathrm{C}\right)$ for first white phase was required by 'Lucyna', 'Notè', 'Orkolija', 'Pandy 301' and 'Rovesnica' cultivars. SAT of 'Orkolija' required for mother cells phase was lower than average and higher than average for first white phase compared to other cultivars. This indicates that the period between mother cells phenological phase and the beginning of first white phase was long. Average SAT $\left(\geq 3^{\circ} \mathrm{C}\right)$ for full bloom phase in sour cherry plants was $473^{\circ} \mathrm{C}$. Significantly lower SAT $\left(433^{\circ} \mathrm{C}\right)$ for full bloom phase was required for hybrid M 323. The highest SAT required for full bloom was identified for 'Orkolija' and 'Note' cultivars, $499^{\circ} \mathrm{C}$ and $491^{\circ} \mathrm{C}$ respectively. SAT required for full bloom of 'Lucyna', 'Pandy 301', 'Rovesnica' and 'Vytėnų žvaigždè' was similar to average. Average SAT $\left(\geq 3^{\circ} \mathrm{C}\right) 691^{\circ} \mathrm{C}$ for beginning of fruit germ phase was required. Significant differences were obtained between cultivar 'Pandy 301' and cultivars 'Lucyna', 'Note', 'Orkolija' and 'Rovesnica'. The lowest SAT for mother cells, first white, full bloom and fruit germ phase, compared to other cultivars, were required by hybrid M 323. Development of generative organs of this hybrid started earlier and therefore it shifted into period in which the possibility of spring frost was higher.

According to long term observations, spring frost is chronologically regular, i.e. it occurs almost at the same time. It was established that the most likely periods for spring frost in Lithuania are $2^{\text {nd }}-5^{\text {th }}, 9^{\text {th }}-14^{\text {th }}, 23^{\text {rd }}-25^{\text {th }}$ of May and $2^{\text {nd }}-8^{\text {th }}$ of June (Lietuvos klimatas, 2007). The average daily temperatures of May according to the data of the last 23 years were used to calculate the possibility of spring frost for each day (Fig. 6). The influence of the

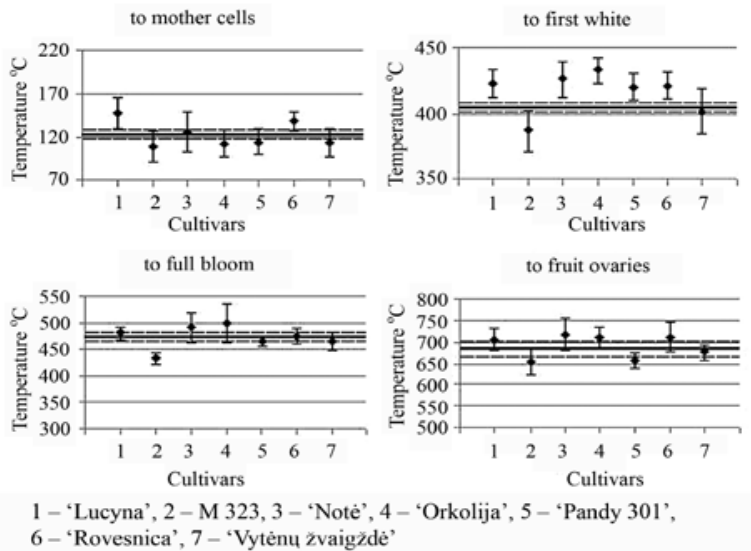

Figure 5. Sum of active temperatures (SAT) $\left(\geq 3^{\circ} \mathrm{C}\right)$ required for the beginning of sour cherry phenophases (mean and standard error of mean are shown)

probability of spring frost on the resistance of sour cherry cultivars in various phenological phases was considered. It was established that resistance to spring frost is a combination of several biological components, which integrate earliness of different phenological phases, their duration and susceptibility of genotype to spring frost at various development stages. Our data shows that SAT $499^{\circ} \mathrm{C}$ is required for cultivar 'Orkolija' to reach full bloom phase, in which pistils are very susceptible to frost. On average such SAT is accumulated on $9^{\text {th }}$ of May, and this phase lasts for 13 days. The probability of spring frost is high in this period; it reaches $55 \%$ on certain days. Plants from the other group, which are most sensitive in the fruit germ phenological phase reach the necessary SAT on the $18^{\text {th }}-22^{\text {nd }}$ of May. The duration of this phenological phase differs between cultivars and lasts for 9-13 days, and the probability of spring frost is lower in this period $(<30 \%)$.

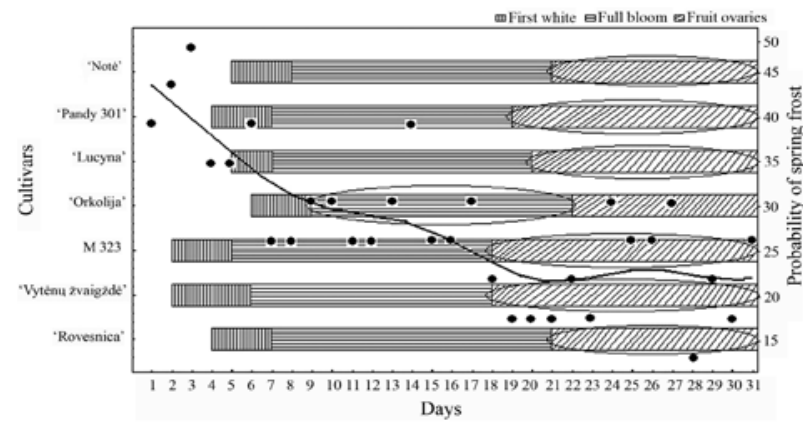

Figure 6. Probability of spring frost for certain day (\%) and different phenological phases of cultivars, ellipsis indicates the phenological phase in which generative organs of cultivars are most susceptible to spring frost

In order to protect fruit trees from spring frost, adequate protection means are necessary. However, more effective method would be growing cultivars with delayed vegetation and which flower after the period with high spring frost probability (Duchovskis et al., 2000; Rodrigo, 2000; Leinonen, Hänninen, 2002; Rugienius et al., 2009). It is very important that the period of sour cherry phenophases, in which generative organs of plants are most susceptible to spring frost, would be as short as possible. If these phenological phases are short, the probability that generative organs of plants will be injured is low.

\section{Conclusions}

1. Resistance of sour cherry to spring frost depends on the genotype and the level of development of generative buds. Different sum of active temperatures 
is required for the beginning of a particular phenological phase in sour cherry: first white requires $387-426^{\circ} \mathrm{C}$, full bloom $433-499^{\circ} \mathrm{C}$ and fruit germ $654-719^{\circ} \mathrm{C}$ of active $\left(\geq 3^{\circ} \mathrm{C}\right)$ temperatures. It indicates the beginning of phenological phases in which the generative organs of sour cherry cultivars are susceptible to spring frost.

2. Spring frost damage to cherry plants depends on the presence or absence of spring frost probability during the phenological phases in which generative organs of plants are most susceptible to spring frost plants of 'Orkolija' are the most susceptible to spring frost in a full bloom phase. The probability of spring frost is high during this phase and it reaches $55 \%$ on certain days. The other studied sour cherry cultivars are most sensitive to spring frost in fruit germ phenological phase. The probability of spring frost in this period is lower than $30 \%$.

\section{Acknowledgments}

This study was carried out within the framework of the long-term research program "Genetics of agricultural and forest plants and purposeful change of genotypes" supported by Ministry of Science and Education of Lithuania.

Received 23112012

Accepted 24042013

\section{References}

Anisimov O. A., Beloluckaja M. A., Lobanov V. A. 2003. Modern changes of a climate in the field of high breadthes of Northern hemisphere. Meteorology and hydrology, 1: 18-31 (in Russian)

Ansari M., Davarynejad G. 2008. The flower phenology of sour cherry cultivars. American Eurasian Journal of Agricultural and Environmental Science, 4 (1): 117-124

DuchovskisP., ŠikšnianienėJ.B., ŠikšnianasT.,Bandaravičienė G. 2000. Development dynamics of generative organs of black currants and their resistance to spring frosts. Sodininkyste ir daržininkystè, 19 (1): 3-14 (in Lithuanian)

Duchovskis P., Stanys V., Sasnauskas A., Bobinas C. 2007. Cold resistance of Prunus domestica L. and Prunus cerasifera Ehrh. in Lithuania. Acta Horticulturae, 734: 299-303

Guerriero R., Viti R., Bartolini S., Iacona C. 2006. Parents for spring frost tolerance in apricot. Acta Horticulturae, 717: 153-156
Iezzoni A. F. 1985. Genetic differences for spring floral bud development among sour cherry cultivars. Acta Horticulturae, 169: 123-126

Leinonen I., Hänninen H. 2002. Adaptation of the timing of bud burst of Norway spruce to temperate and boreal climates. Silva Fennica, 36 (3): 695-701

Lietuvos klimatas. 2007 / compiled by Galvonaite A. et al. Vilnius, 52 p. (in Lithuanian)

Linkosalo T., Carter T. R., Hakkinen R., Hari P. 2000. Predicting spring phenology and frost damage risk of Betula spp. under climatic warming: a comparison of two models. Tree Physiolnog $70(17) \cdot 1175-118$ ? http://dx.doi.org/10́.1093/treephys/20.17.1175

Miranda C., Santesteban L.G., Koyo J. B. 2005. Varıability in the relationship between frost temperature and injury level for some cultivated Prunus species. HortScience, 4 (2): 357-361

Rodrigo J. 2000. Spring frosts in deciduous fruit trees morphological damage and flower hardiness. Scientia Horticulturae, 85.155-173 http://dx.doi.org/10.1016/S0304-4238(99)00150-8

Romanovskaja D., Bakšienè E. 2011. The intluence of climatic change on the beginning of spring season and prediction of apple tree flowering in Lithuania. Sodininkyste ir daržininkystė, 30 (3-4): 29-39 (in Lithuanian)

Rugienius R., Stanys V. 2001. In vitro screening of strawberry nlants for cold resistance Funhutica 177. 269-277 http://dx.doi.org/10.1023/A:1012905106979

Rugienius R., Siksnianas 'I., Gelvonauskiene D., Staniene G., Sasnauskas A., Zalunskaite I., Stanys V. 2009. Evaluation of genetic resources of fruit crops as donors of cold and disease resistance in Lithuania. Acta Horticulturae, 825: 117-123

Stepulaitiene I., Stanys V. 2009. Resistance to spring frost of sour cherry flowers and fruit ovaries. Sodininkyste ir daržininkyste, 28 (4): 27-34 (in Lithuanian)

Szabo Z., Soltesz M., Nyeki J. 1996. Frost injury to flower buds and flowers of cherry varieties. Acta Horticulturae, 410: 315-321

Szalay L. 2006. Comparison of flower bud development in almond, apricot and peach genotypes. International Journal of Horticultural Science, 12 (2): 93-98

Szpadzik E., Matulka M., Jadczuk-Tobjasz E. 2009. The growth, yielding and resistance to spring frost of nine sour cherry cultivars in central Poland. Journal of Fruit and Ornamental Plant Research, 17 (2): 139-148

Walther G. R. 2003. Plants in a warmer world. Perspectives in Plant Fonlong Funlution and Systematics 6: 169-185 http://dx.doi.org/10.1078/1433-8319-00076

Куперман Ф. М., Ржанова Е. И., Мурашев В. В., Львова И. Н., Седова Е. А., Ахундова В. А., Щербина И. П. 1982. Биология развития культурных растений. Москва, 343 с.

ISSN 1392-3196 / e-ISSN 2335-8947

Zemdirbyste-Agriculture, vol. 100, No. 2 (2013), p. 175-178

DOI $10.13080 /$ z-a.2013.100.022

\title{
Paprastosios vyšnios (Prunus cerasus L.) atsparumas šalnoms yra susijęs su generatyvinių pumpurų raida
}

\author{
I. Stepulaitiené ${ }^{1}$, A. Žebrauskiené ${ }^{2}$, V. Stanys ${ }^{1,2}$ \\ ${ }^{1}$ Lietuvos agrarinių ir miškų mokslų centro Sodininkystès ir daržininkystès institutas \\ ${ }^{2}$ Aleksandro Stulginskio universitetas
}

\section{Santrauka}

Pavasario šalnos turi įtakos vyšnių derejjimo stabilumui ir derlingumui. 2010-2012 m. LAMMC Sodininkystės ir daržininkystès instituto Sodo augalu genetikos ir biotechnologijos skyriuje paprastosios vyšnios (Prunus cerasus L.) kelių veislių šakos $30 \mathrm{~min}$ dirbtinai šaldytos $-4{ }^{\circ} \mathrm{C}$ temperatūroje. Stebèta šių augalų fenologinių fazių kaita ir įvertinta šalnos pasireiškimo tikimybė. Nustatyta, kad esant ịvairioms fenologinėms fazèms pagal atsparumą pavasario šalnoms veisles galima skirstyti i dvi grupes. Pirmajai grupei priskirti augalai, šalčiui jautriausi esant vaisių užuomazgų fenologinei fazei. Antrajai grupei priskirti augalai, šalčiui jautriausi žydejjimo metu. Nustatyta, kad veislès atsparumas šalnoms yra keleto biologinių komponentų derinys. Veislès 'Orkolija' augalų pažeidimas $-4{ }^{\circ} \mathrm{C}$ temperatūroje žydejjimo metu, lyginant su kitomis fenologinèmis fazèmis, buvo didžiausias ir esmingai skyrèsi nuo kitu veislių. Tai rodo, kad vyšnios augalu atsparumas pavasario šalnoms priklauso nuo generatyviniu organų išsivystymo lygio šalnų metu, o derejjimo stabilumas - dar ir nuo jautriausių fenologinių fazių trukmès bei šalnų tikimybės šalčiui jautriausių fenologinių fazių tarpsniu. Stabiliu derèjimu pasižymi tu veisliu vyšnios, kurių augalai turi trumpiausias fenofazes, kai generatyviniai organai yra labiausiai pažeidžiami šalčio, o šios fenologinės fazès būna tuo metu, kai šalnų tikimybẻ yra nedidelè.

Reikšminiai žodžiai: fenologinè fazè, pavasario šalnos, Prunus cerasus. 